\title{
KERONCONG GAYA KEEMPAT (KAJIAN BENTUK DAN GAYA PENYAJIAN)
}

\author{
Rully Aprilia Zandra \\ Program Studi Pendidikan Seni Tari dan Musik - Seni dan Desain Universitas Negeri Malang \\ rullyzandra.fs@um.ac.id
}

\begin{abstract}
Keroncong is a genre of music that evolves and lives in Indonesia. Many versions have been raised about the origin of keroncong. There is a version states that keroncong music was originated from Portuguese, others state that keroncong is an Indonesian local genius. Surabaya as one of the cities in Indonesia with its dinamic political development was very possible has influence to its musical history, form, and presentation style. Based on this background, the question research is how are the form and presentation style of keroncong music in Surabaya? The method used in this research was qualitative, and case study approach. The results showed that Surabaya keroncong style is charachterized by the musical forms, lyric, presentation, instruments, and tuning.
\end{abstract}

Keywords: Keroncong, Surabaya Keroncong Style, Markasan.

\begin{abstract}
Abstrak: Keroncong adalah genre musik yang berkembang dan hidup di Indonesia. Banyak versi telah dikemukakan tentang asal muasal keroncong. Terdapat versi yang menyatakan bahwa musik keroncong berasal dari Portugis, ada juga yang menyatakan bahwa keroncong adalah local genius bangsa Indonesia. Surabaya, sebagai salah satu kota di Indonesia dengan perkembangan politik yang dinamis, disinyalir memiliki pengaruh terhadap sejarah, bentuk, dan gaya penyajian musik keroncongnya. Rumusan masalah dalam penelitian ini adalah bagaimana bentuk dan gaya penyajian musik keroncong di Surabaya? Metode yang digunakan dalam penelitian ini adalah kualitatif dengan pendekatan studi kasus. Hasil penelitian menunjukkan bahwa keroncong gaya Surabaya memiliki kekhasan pada bentuk musik, lirik, penyajian, alat musik, dan stem.
\end{abstract}

\section{Kata kunci: Keroncong, Keroncong gaya Surabaya, Markasan.}

Keroncong adalah salah satu genre ${ }^{1}$ musik yang berkembang dan gaya hidup di Indonesia. Banyak versi yang telah dikemukakan oleh para ahli mengenai asalusul musik keroncong. Ada versi yang menyatakan bahwa musik keroncong berasal dari Portugis, ada pula yang berpendapat bahwa keroncong adalah local genius bangsa Indonesia. Selain itu, ada pula pendapat yang menyatakan bahwa keroncong adalah musik hasil pembauran antara musik Barat (Portugis) dan musik Timur (Indonesia).

\footnotetext{
${ }^{1}$ Istilah genre memiliki makna suatu tradisi penampilan

${ }^{2}$ Desrilland, "Kroncong Musik Khas Indonesia: Sebuah Kajian

Musikologis", (Tesis untuk meraih gelar Magister

Humaniora, Program Pengkajian Seni Pertunjukan

Universitas Gadjah Mada. Jogjakarta: Program Pasca Sarjana

Universitas Gadjah Mada, 2001), p. 42-47; Lihat juga Andjar

Any dkk., "Musik Keroncong Menjawab Tantangan
}

Secara musikal dalam perkembangannya, keroncong telah memiliki tiga macam gaya permainan. Sebagaimana telah diakui oleh masyarakat musik Indonesia terdapat tiga permainan musik keroncong yakni pembawaan keroncong gaya Lama, gaya Jakarta, dan gaya Solo. ${ }^{2}$ Pada artikel ini akan diperkenalkan kembali gaya yang keempat yakni gaya Surabaya. ${ }^{3}$

Surabaya sebagai salah satu kota metropolitan yang berpenduduk sangat plural memiliki potensi sebagai tempat

\footnotetext{
Jamannya" (Makalah untuk Materi penataran seni musik Direktorat Kesenian di Cisarua Bogor, 3-12 September 1997), p. 2.

3 Zandra, 2014, Sejarah Musik Keroncong di Surabaya. Jurnal Imaji. UNY Pree:ogyakarta p74-84
} 
berkembangnya berbagai jenis musik termasuk musik keroncong. Masyarakat Surabaya secara umum telah dikenal memiliki identitas budaya yang sangat khas, yang tercermin baik dalam hal kreativitas berkesenian, maupun interaksi sosialnya. Berkaitan dengan perkembangan musik keroncong di Indonsia, rupanya Surabaya juga memiliki andil yang perlu diperhitungkan. Secara historis dinamika perkembangan musik keroncong di Indonesia sangat dipengaruhi oleh perkembangan sosial politik. ${ }^{4}$ Surabaya sebagai salah satu kota di Indonesia yang juga memiliki perjalanan perkembangan politik yang sangat historical hingga memiliki sebutan Kota Pahlawan. Hal tersebut memungkinkan berpengaruh terhadap perkembangan musik keroncong khususnya di Surabaya.

Secara umum masyarakat hanya mengenal keroncong gaya Lama, gaya Jakarta, dan gaya Solo dengan karakteristik musikalnya masing-masing. Musik keroncong yang berkembang di Surabaya jika dicermati juga memiliki karakteristik yang sangat khas. Kekhasan itu dapat diasumsikan sebagai cermin kultur budaya masyarakat Surabaya. Hasil pengamatan lapangan menunjukkan, bahwa ternyata musik keroncong di Surabaya juga memiliki eksistensi. Secara musikal, musik keroncong yang hidup dan berkembang di Surabaya memiliki gaya permainan yang sangat berbeda bila dibandingkan dengan gaya Lama, gaya Jakarta, maupun gaya Solo. Perbedaan tersebut terletak pada teknik permainan, lirik, maupun gaya permainannya yang sangat khas yang dapat diasumsikan sebagai gaya Surabaya. Akan tetapi istilah Keroncong gaya Surabaya itu belum diakui oleh masyarakat, meskipun pada kenyataannya ada.

Keunikan dan kekhasan musik keroncong yang berkembang di Surabaya sebagai manifestasi kekayaan budaya atau genius product $t^{5}$ dari local genius nenek moyang bangsa Indonesia inilah yang menggelitik peneliti untuk mengkaji lebih dalam. Penelitian tentang musik keroncong ini lebih difokuskan pada musik keroncong di Surabaya, khususnya tentang gaya Surabaya.

\footnotetext{
${ }^{4}$ Desrilland, (2001), p. 1.

${ }^{5}$ Andjar Any, (1997), p. 2

${ }^{6}$ Sulistiohadi, "Perkembangan Musik Keroncong Siaran RRI Surabaya Tahun 1960 hingga Tahun 1999”, Skripsi untuk
}

Penelitian tentang musik keroncong di Surabaya pernah dilakukan oleh peneliti terdahulu yaitu Sulistyohadi dalam bentuk skripsi, dengan judul "Perkembangan Musik Keroncong Siaran RRI Surabaya Tahun 1960 Hingga Tahun 1999". Hasil penelitian Sulistyohadi mengungkapkan: (1) Perkembangan musik keroncong RRI Surabaya sangat pesat dan mampu menarik minat masyarakat luas terutama generasi muda karena RRI Surabaya mempunyai kelebihan yang dapat menjangkau seluruh lapisan masyarakat (lapisan bawah). Perkembangan musik keroncong dari tahun 1960 sampai 1999 semakin matang dan mempunyai mutu yang dapat diperhitungkan; (2) Musik keroncong RRI Surabaya mampu menempatkan diri sebagai musik yang memiliki kualitas dan mengandung nilai seni yang tinggi sehingga RRI Surabaya memberikan kesempatan kepada grup-grup orkes keroncong maupun penyanyi vokal untuk dapat tampil dalam setiap acara yang disiarkan secara khusus untuk perkembangan musik keroncong; (3) RRI Surabaya berusaha keras untuk melestarikan budaya tradisional terutama musik keroncong dengan mengadakan apresiasi musik keroncong, Festival Bintang Radio, dan acara-acara lainnya. ${ }^{6}$

Informasi tersebut menjelaskan bahwa Sulistyohadi sama sekali tidak mengungkap tentang historis, bentuk penyajian, maupun gaya musikal keroncong di Surabaya.

Berdasarkan latar belakang seperti yang telah diuraikan tersebut, maka rumusan permasalahan yang diangkat adalah bagaimana bentuk dan gaya penyajian musik keroncong di Surabaya?

\section{TEORI}

Musik keroncong berkembang di pulau Jawa pada abad ke-20 yang dalam perkembangannya terpengaruh oleh musikmusik daerah (tradisional) terutama di Jakarta, Jawa Tengah yaitu Yogyakarta dan Surakarta, serta Jawa Timur (Surabaya). ${ }^{7}$ Musik keroncong ini dipengaruhi oleh musik gamelan (pentatonis).

Perkembangan di Jawa Timur dimulai

\footnotetext{
meraih gelar Sarjana Pendidikan, Program Pendidikan Seni

Drama, Tari dan Musik Universitas Negeri Surabaya.

(Surabaya: Universitas Negeri Surabaya, 2000), p. 54-55.

${ }^{7}$ Harmunah, (1978), p. 9-10
} 
dari adanya teater rakyat komedi stambul yang mempergunakan lagu-lagu keroncong di panggung pertunjukan-pertunjukan selingan maupun untuk bagian-bagian dari drama itu sendiri. Dari itulah timbulah suatu tipe keroncong yang disebut stambul. ${ }^{8}$ Elemenelemen dasar atau aspek musikal keroncong ini dapat kita lihat dari bentuk musik dan repertoarnya.

Musik keroncong mempunyai lima ciri khas, ${ }^{9}$ yaitu bentuk, harmoni, ritme, alat-alat dan gaya atau pembawaan.

\section{Bentuk}

Pengertian istilah bentuk adalah suatu gagasan atau ide yang nampak dalam penyalahgunaan/susunan semua unsur musik dalam sebuah komposisi (melodi, irama, harmoni, dan dinamika). ${ }^{10}$ Bentuk dalam sebuah musik keroncong merupakan keistimewaan genre musik ini, sebab aturan bentuknyalah yang menjadi identitas sekaligus pembeda antara jenis lagu keroncong yang satu dengan lainnya. Harmunah dalam bukunya, Musik Keroncong - Sejarah, Gaya, dan Perkembangan (1987) mengungkapkan terdapat beberapa jenis musik keroncong, antara lain: Keroncong Asli, Stambul, Langgam dan Lagu Ekstra. ${ }^{11}$

Harmoni keroncong asli dibuat dalam tangga nada mayor dan membentuk kadens lengkap I - IV - V - I. Modulasi II - V, dan hampir selalu setelah modulasi kedominan dilanjutkan dengan akord IV.

Harmoni langgam dibuat dari tangga nada mayor, dan tangga nada yang diarahkan dari musik daerah. Ciri harmonisasinya hampir sama dengan jenis keroncong asli, yaitu membentuk kadens lengkap I - IV - V - I, dan modulasi II - V.

Sedangkan stambul, meski tangga nadanya juga mayor dan ciri harmonisasinya adalah membentuk kadens lengkap I - IV - V - I, namun untuk introduksinya menggunakan akord I dengan peralihan ke akord IV.

\section{Ritme}

\footnotetext{
${ }^{8}$ Ernst Heins, Kroncong and Tanjidor - Two cases of urban folk music in Jakarta, Asian Musik VII-I, Journal of the society for Asian Musik, 1975, p. 21.

${ }^{9}$ Harmunah, (1987), p. 17

${ }^{10}$ Karl-Edmund Prier, Ilmu Bentuk Musik, (Yogyakarta: Pusat Musik Liturgi, 1996), p. 2
}

Di dalam musik keroncong, jenis alat yang berperan sebagai pengiring dan pemegang ritmis adalah alat-alat musik ukulele, banjo, cello, dan contrabass.

\section{Alat-alat}

Alat musik keroncong asli dipakai sebagai ukuran adalah tujuah macam, yaitu biola, seruling, gitar, ukulele, banjo, selo, dan kontrabas. Jadi apabila sudah ada ketujuh macam alat musik keroncong ini, maka permainan musik keroncong sudah dapat dikatakan lengkap.

\section{Gaya atau Pembawaan}

Gaya adalah cara. Cara irama dan lagu dalam bernyanyi dan bermusik, cara melakukan, cara berlagaknya lagu, maupun cara berperangainya sebuah musik keroncong. ${ }^{12}$ Gaya atau style dapat pula diartikan pembawaan atau cara penyajian, dalam hal ini yang dimaksud adalah cara penyajian atau cara memainkan musik keroncong.

Terdapat tiga jenis gaya atau pembawaan pada musik keroncong, yaitu pembawaan dari setiap alat, pembawaan vokal, dan pembawaan dari semua alat secara kelompok.

Musik keroncong sebagai musik khas Indonesia dikenal oleh masyarakat (khususnya masyarakat musik) pada umumnya ada tiga macam gaya dalam literatur-literatur cetak, yaitu pembawaan Keroncong Gaya Lama, pembawaan Keroncong Gaya Jakarta, dan pembawaan Keroncong Gaya Surakarta (Solo). ${ }^{13}$

Ketiga gaya tersebut di awal dapat ditabelkan sebagai berikut:

Tabel 1 Gaya Lama, Jakarta, Solo

\footnotetext{
${ }^{11}$ Harmunah, (1987), p. 17

12 W.J.S. Poerwadarminta, Kamus Umum Bahasa Indonesia Ed. III, (Jakarta: Balai Pustaka, 2003), p. 354.

${ }^{13}$ Budiman BJ., Mengenal Keroncong Dari Dekat, (Jakarat:

Tanpa Penerbit, 1979), p. 42.
} 


\begin{tabular}{|c|c|c|c|}
\hline Pembeda & Gaya Lama & $\begin{array}{c}\text { Gaya } \\
\text { Jakarta }\end{array}$ & Gaya Solo \\
\hline Uculele & $\begin{array}{c}\text { Dua buah } \\
\text { stem A dan } \\
\text { E, digaruk }\end{array}$ & $\begin{array}{l}\text { Stem A, } \\
\text { digaruk }\end{array}$ & $\begin{array}{c}\text { Stem A, } \\
\text { dipetik } \\
\text { 'Kenthululul' }\end{array}$ \\
\hline Banjo & -- & $\begin{array}{l}\text { Dipetik } \\
\text { satu senar } \\
\text { saja }\end{array}$ & $\begin{array}{l}\text { Digaruk akor } \\
\text { lengkap }\end{array}$ \\
\hline Gitar & $\begin{array}{l}\text { Gitar lebih } \\
\text { dari satu, not } \\
\text { sinkup dan } \\
\text { treiul, } \\
\text { terkadang } \\
\text { ditambahkan } \\
\text { mandolin }\end{array}$ & $\begin{array}{l}\text { Irama } \\
\text { grebekan, } \\
\text { tenang } \\
\text { lalu tiba- } \\
\text { tiga cepat }\end{array}$ & Tenang \\
\hline Celo & --- & $\begin{array}{c}\text { Celo } \\
\text { lincah, } \\
\text { tidak } \\
\text { melankoli } \\
\mathrm{s}\end{array}$ & $\begin{array}{c}\text { Banyak } \\
\text { variasi, } \\
\text { meniru gaya } \\
\text { kendang, } \\
\text { melankolis }\end{array}$ \\
\hline $\begin{array}{l}\text { Kontraba } \\
\mathrm{s}\end{array}$ & --- & $\begin{array}{c}\text { Dipetik } \\
\text { bass dan } \\
\text { kontranya }\end{array}$ & $\begin{array}{c}\text { Tidak hanya } \\
\text { bas dan } \\
\text { kontra yang } \\
\text { dibunyikan }\end{array}$ \\
\hline Flute & --- & $\begin{array}{c}\text { Saling isi } \\
\text { dengan } \\
\text { biola }\end{array}$ & $\begin{array}{c}\text { Saling isi } \\
\text { dengan biola } \\
\text { tidak } \\
\text { arogan/samar } \\
\text { menjadi } \\
\text { background } \\
\text { vokal }\end{array}$ \\
\hline Biola & --- & $\begin{array}{l}\text { Saling isi } \\
\text { dengan } \\
\text { flute }\end{array}$ & $\begin{array}{c}\text { Saling isi } \\
\text { dengan flute }\end{array}$ \\
\hline Lirik & $\begin{array}{c}\text { Alam, } \\
\underset{n}{\text { kepahlawana }}\end{array}$ & $\begin{array}{c}\text { Alam, } \\
\text { kepahlawa } \\
\text { nan }\end{array}$ & $\begin{array}{c}\text { Alam, } \\
\text { kepahlawana } \\
\mathrm{n}\end{array}$ \\
\hline $\begin{array}{l}\text { Harmo } \\
\text { nisasi }\end{array}$ & $\begin{array}{l}\text { Tonika, sub } \\
\text { dominan, } \\
\text { dominan }\end{array}$ & $\begin{array}{c}\text { Tonika, } \\
\text { sub } \\
\text { dominan, } \\
\text { dominan }\end{array}$ & $\begin{array}{c}\text { Tonika, sub } \\
\text { dominan, } \\
\text { dominan }\end{array}$ \\
\hline
\end{tabular}

Sumber: Any (1997:2); Budiman (1979:42); Harmunah (1987:17)

\section{METODE}

Penelitian ini menggunakan metode kualitatif dengan pendekatan studi kasus. Teknik pengumpulan data dilakukan dengan: (1) pengamatan, (2) wawancara, dan (3) dokumentasi. Sumber data yang digunakan berasal dari: (1) narasumber / informan, (2) data tertulis, (3) foto, dan (4) rekaman musik. Validitas data diuji dengan menggunakan triangulasi data. Triangulasi yang dipakai dalam penelitian ini adalah triangulasi waktu, triangulasi sumber, dan triangulasi metode. Teknik analisis data yang digunakan adalah analisis domain.

\section{HASIL}

\section{Bentuk Musik Keroncong di Surabaya}

Terdapat tiga struktur mencolok yang selalu dimunculkan dalam penyajian keroncong secara umum dan berlaku juga pada keroncong gaya Surabaya yaitu introduction, interlude, dan coda.

Introduction dalam lagu yang dibawakan orkes keroncong di Surabaya terdiri atas dua bagian, bagian pertama dibawakan oleh pemain solo (solist), dan bagian kedua dibawakan secara bersama-sama (tutti) oleh seluruh pemain. Bagian pertama dibawakan secara improvisasi dengan tempo bebas ( $a d$ lib. = ad libitum), biasanya terdiri atas tiga kalimat, yakni kalimat a, b, dan c, yang dibawakan oleh solo flute, solo biola, solo gitar, atau oleh ketiga alat musik tersebut secara bergantian. Misalnya kalimat a dibawakan oleh solo biola, kalimat b oleh solo flute, dan kalimat c oleh solo gitar, atau dengan kemungkinan pola gabungan lainnya.

Cara membawakan introduction bagian pertama adalah bila kalimat a berakhir, maka seluruh alat musik pengiring menyambutnya pada tonic chord dengan tremolo. Setelah itu dilanjutkan dengan kalimat b yang berakhir pada dominant chord dengan bunyi serempak mengejutkan (akor pendek), kemudian masuk kalimat c yang berakhir dengan tonic chord. Untuk mengakhiri permainan kalimat c, pembawanya (solist) biasanya melakukan perlambatan tempo $($ rit $=$ ritardando $)$ yang bertujuan memberi kode bahwa kalimat c akan berakhir sehingga seluruh pemain dapat bersiap siap untuk menyambutnya dengan tempo keroncong (in tempo) dalam tonic chord. Setelah itu dilanjutkan dengan introduksi bagian kedua, yakni dengan memainkan kalimat e sepanjang empat birama dari essential component secara bersama-sama.

Sebelum masuk putaran kedua atau ulangan, biasanya diselingi oleh musik instrumental, bagian inilah yang dinamakan dengan interlude.

Memainkan lagu jenis keroncong interlude-nya adalah kalimat e dari essential component selama 4 birama. Berbeda dengan jenis langgam, interlude selalu memainkan bentuk A' secara utuh selama 8 birama. Pada lagu jenis stambul I, tidak menggunakan interlude, karena essential component lagu 
jenis ini terdiri atas musik dan vocal yang saling bersahut-sahutan, sedangkan untuk jenis stambul II, interlude biasanya memainkan bentuk B secara utuh.

Coda merupakan bagian penutup dari sebuah lagu ataupun komposisi musik. Pada lagu-lagu keroncong, baik untuk jenis keroncong, langgam maupun stambul, bagian ini biasanya selalu memainkan lintas akor yang umum disebut overgang.

\section{Gaya Permainan Keroncong Gaya Surabaya}

Gaya Surabaya memiliki persamaan permainan ukulele dengan gaya Jakarta dalam hal engkel dan dobelnya. Irama engkel dipukul empat kali, sedangkan pada irama dobel dipukul delapan kali dalam tiap biramanya untuk memberi dinamika yang menggelitik. Namun irama dobel maupun engkelnya tidak dilakukan hanya dengan menggaruk seluruh senar bersamaan tetapi juga digabungkan dengan teknik petik ketlulululnya gaya Surakarta.

Stem alat yang digunakan berbeda dengan stem gaya Jakarta yang menggunakan stem A maupun gaya lama yang menggunakan dua ukulele dengan stem A dan E. Ukulele gaya Surabaya menggunakan stem E dan hanya menggunakan satu instrument ukulele saja, hal ini serupa dengan penggunaan ukulele gaya Surakarta.

Pada permainan gaya Surabaya banjo dipukul dengan cara digaruk sesuai dengan akord lengkap. Pukulannya di sela-sela ukulele, sehingga mereka saling mengisi antara ukulele dan banjo. Walaupun irama sudah pindah ke irama dobel, yang kecepatannya menjadi dua lipat, namun mereka tetap saling mengisi, sehingga menimbulkan ketukan-ketukan yang berkejarkejaran. Meskipun untuk memainkan gaya prolong ini diperlukan permainan yang cepat dan trilen, tetapi bagi yang sudah ahli hal itu tidak merepotkan, banjo dan ukulele tetap berkejar-kejaran tanpa beraturan. Dalam hal ini permainan banjo gaya Surabaya sama dengan permainan banjo gaya Surakarta (Solo).

Menurut Pareng seorang praktisi keroncong di RRI Surabaya, keroncong Gaya Jawa Timur memiliki ciri utama pada demungan gitar (dung... dang... dung...), sedangkan pola permainan mandolinnya dapat digantikan dengan cak atau biola. ${ }^{14}$ Pola permainan gaya Surabaya atau gaya Markasanan saat itu permainan gitarnya hanya ndemung yang artinya mengikuti jalannya melodi lagu dengan irama yang konstan. Dapat dicontohkan dengan membunyikan empat petikan dalam satu birama, demikian pula dalam irama dobel sehingga seolah-olah menjaga kestabilan lagu.

Keroncong gaya Surabaya menitikberatkan pada dominasi permainan cello dan mandolin (jika tanpa gitar). ${ }^{15}$ Permainan cello dibuat begitu mendominasi sehingga sepintas cenderung seperti gaya Jakarta tetapi permainannya terkesan lebih improvisatoris. Uniknya, meski permainan engkelnya tidak semelankolis gaya Solo, namun permainan cello-nya memiliki fungsi yang sama dengan cello gaya Solo yaitu penentu irama, dari engkel ke dobel maupun sebaliknya. Perlu dicermati bahwa pola kendangan Jawa Tengah dan Jawa Timur memiliki perbedaan yang cukup signifikan, sehingga adopsi pola pukulan kendang pada cello-nya pun berbeda.

Teknik permainan kontrabas (controbass) pada gaya Surabaya menggunakan perpaduan antara kedua gaya yang ada, mengingat pada gaya lama belum masuk instrumen kontrabas. Pada bagian tertentu yang dipetik hanya akor dan kontranya saja, namun pada bagian lain ada kalanya memberikan variasi-variasi pemanis sehingga tidak monoton seperti gaya Jakarta.

Biola dan flute, seperti pada gaya yang lain, kedua alat ini saling mengisi dalam gaya permainannya cenderung mirip dengan gaya Solo, yakni tidak terlalu arogan dalam mendominasi. Selain menyampaikan introduction, musik, dan coda, waktu vokal juga mengisi, isian pada waktu penyanyi menyanyi hanya sebagai background saja, seperti layaknya rebab pada kerawitan, dia hanya bergumam sesuai dengan akornya. Ketika penyanyi mengambil mengambil napas barulah mereka muncul tetapi itupun tidak

\footnotetext{
15 Diperoleh dari wawancara dengan Musafir Isfanhari, seorang praktisi musik di Banyu Urip Lor III, tanggal 5 Maret 2004.
}

${ }^{14}$ Diperoleh dari Wawancara dengan Pareng, praktisi musik di RRI Surabaya tanggal 9 Januari 2005. 
begitu mencolok. Hanya pada bagian yang dirasa perlu aksen barulah dibunyikan dengan crescendo.

Bertumpu pada wawancara lainnya, dapat pula disimpulkan bahwa yang dimaksud gaya Surabaya saat ini bukan lagi gaya Markasan saja, justru ciri permainan di Surabaya adalah penggabungan dari keempat gaya yang pernah ada itu.

Keroncong gaya Surabaya juga memainkan empat bentuk musik keroncong, yaitu keroncong asli, stambul, langgam, dan lagu lagu ekstra. Dalam bentuk permainan para orkes keroncong di Surabaya telah banyak memberikan pengembangan dan variasi dari pakem dasarnya.

Pembahasan pergeseran dari pakem ini dapat pula didapati pada contoh orkes keroncong Fajar Satria. Orkes Keroncong Fajar Satria adalah salah satu Orker keroncong yang pernah dianggap berani dalam membuat sebuah aransemen. Meskipun tidak terlalu menyimpang dari pakem progresi dalam keroncong, namun ini sudah merupakan sebuah perombakan besar jika dilihat dari kacamata keroncong, yang mana salah satu aturan dasarnya adalah sebuah komposisi lagu dengan progresi yang tetap. Perubahan progresinya adalah sebagai berikut.

Penambahan progresi pada keroncong asli yang digunakan adalah: chord I ke chord $\mathrm{V}$ melalui jembatan chord ii / chord dua minor (dua ketuk) dan vii / tujuh diminished (dua ketuk). Chord I yang ditahan selama tiga bar, pada bar ke-2nya diganti accord I6 / chord pertama enam. Sehingga bentuk progressive chord dalam aransemen gaya Surabaya menjadi:

$\begin{array}{llllllll}I \ldots & i i . v i i^{\circ} . & V \ldots & V \ldots & V \ldots & V \ldots & I \ldots & I \ldots \\ V \ldots & I I \ldots & V \ldots & V \ldots & I \ldots & I V . V . & I \ldots & I \ldots \\ V \ldots & V \ldots & I V \ldots & I V \ldots & V \ldots & V \ldots & I \ldots & I \ldots \\ I V \ldots & I V . V . & I \ldots & i i . v i i^{\circ} . & I V \ldots & I V \ldots & I \ldots & I \ldots \\ V \ldots & V \ldots & I \ldots & I V . V . & I I \ldots & I I \ldots & V \ldots & V \ldots \\ I \ldots & I 6 & I \ldots & i i . v i i^{\circ} . & V \ldots & I \ldots & I V . V . & I \ldots \\ V \ldots & V \ldots & I \ldots & I \ldots & I \ldots & V \ldots & V \ldots & I \ldots\end{array}$




\section{I ... Coda}

akan disajikan dalam gaya Surabaya menjadi sebagai berikut:

\begin{tabular}{|c|c|c|c|}
\hline$I \ldots$ & $I V . V$ & $I \ldots$ & $I \ldots$ \\
\hline$V \ldots$ & $V \ldots$ & $I \ldots$ & I. I6. \\
\hline$I \ldots$ & $I V . V$ & $I \ldots$ & $I \ldots$ \\
\hline$V \ldots$ & $V \ldots$ & $I \ldots$ & I. I7. \\
\hline$I V \ldots$ & $I V \ldots$ & $I \ldots$ & I. I\#din \\
\hline$i i \ldots$ & IV/ii ... & $V \ldots$ & $V \ldots$ \\
\hline$V \ldots$ & I. I7. & $I V . V$ & $I \ldots$ \\
\hline$I \ldots$ & $V \ldots$ & $V . V 7$ & I. Isus \\
\hline & Coda & & \\
\hline
\end{tabular}

Berdasar perbandingan itu, dapat dikatakan bahwa pada langgamlah perubahan yang paling banyak dibuat pada pembawaan gaya Surabaya

Sedangkan, progresi chord pada lagu ekstra berbeda dengan jenis lagu keroncong, stambul, maupun langgam. Hal ini dikarenakan yang disebut lagu ekstra adalah lagu yang progresi chord-nya tidak terpatok pada progresi lagu keroncong, stambul I, stambul II, dan langgam. Contohnya adalah lagu jali-jali, lagu daerah dan lainnya yang memiliki bentuk khusus.

Dikarenakan jenis lagu ini memiliki pola khusus dan tidak terikat, maka peluang musik keroncong dapat mengikuti perkembangan jaman maupun penyesuaian dengan musik etnis terbuka lebar dalam jenis lagu ini. Pada artikel lain penulis jelaskan pula tentang kekhasan gaya Surabaya, khususnya karya Markasan yang justru hanya memainkan peranannya pada lagu ekstra ini saja.

Modifikasi tidak hanya terjadi pada tiga dari empat jenis lagu keroncong saja. Modofikasi juga terjadi pada sebagian organologi instrumen musiknya.

Secara umum bentuk alat musik dalam bezzeting tujuh sudah banyak perubahan baik bentuk maupun cara perlakuannya, kecuali pada flute dan biola.

Cello dan kontrabas merupakan alat musi gesek yang kemudian difungsikan sebagai alat musik yang dipetik (pizzicato). Secara otomatis kondisi fisiknya pun akhirnya berubah, contohnya senar logam pada kedua alat itu dalam formasi orkes keroncong diganti dengan dawai yang berbahan dasar kulit atau nilon.

Demikian juga yang terjadi pada cuk. Bahan senarnya kini diganti nilon dengan alasan: (1) mempermudah melakukan teknik kentlululul, dan (2) harga relatif murah. Namun, kelemahan struktur ini adalah sulitnya mencapai stem A sebagai nada stem aslinya. Sebagai solusi terkadang pada beberapa orkes stemnya diturunkan menjadi stem E. Stem E berisikan nada $\mathrm{e}, \mathrm{b}$, dan $\mathrm{g}$.

Strings logam yang dipakai pada Cak atau banyo serta biola seniman keroncong di Surabaya sebagian besar bukan strings Biola dan banyo asli tetapi strings gitar yang ditipiskan secara manual dengan menggunakan amplas. Berhubung bukan produksi standar yang terukur, maka memang ada peluang hasilnya tidak rata dan tidak presisi. Jika proses penipisannya kurang merata tentu memperbesar resiko putus saat melakukan stem atau fine tuning.

Resiko string putus pada banjo diminimkan dengan mengubahnya menjadi stem E menjadi stem B saja. Stem B ini memiliki susunan nada $b$, fis, dan $d$. Sementara stem E sebagai stem awalnya beranggotakan nada e, b, dan $g$.

Berdasar keterbatasan senar, keterbatasan produksi strings, serta organologi intrumen yang digunkan pada keroncong di Surabaya dapat di rangkum sebagai berikut:

\section{Ukulele (cuk)}

dalam Stem E

dawai 1. e

dawai 2. b

dawai 3. g

\section{Banyo (cak)}

Stem B

dawai $1 . b$

dawai 2. fis

dawai 3. d

\section{Gitar}

Stem E

dawai 1. e

dawai 2. b

dawai 3. g

dawai 4. d 
dawai 5. a

dawai 6. e

Flute

\section{Biola}

Stem in C : normal position

\section{Stem E}

dawai 1.e

dawai 2. a

dawai 3. d

dawai 4. $g$

Cello

Stem D

dawai 1. d

dawai 2. g

dawai 3. c

\section{Kontrabas}

Stem G

dawai $1 . \mathrm{g}$

dawai 2. d

dawai 3. a

dawai 4. c

Mengacu pada seluruh modifikasi dan perbedaan dasar yang telah dipaparkan. Persamaan dan perbedaan musik keroncong gaya Surabaya dengan musik keroncong gaya Lama, gaya Jakarta, dan gaya Solo dapat ditabelkan sebagai berikut:

Tabel 2 Persamaan dan Perbedaan Keroncong Gaya Surabaya terhadap Gaya Lama, gaya Jakarta, dan gaya Solo

\begin{tabular}{|c|c|c|c|c|}
\hline $\begin{array}{c}\text { Pembe } \\
\text { da }\end{array}$ & $\begin{array}{l}\text { Gaya } \\
\text { Lama }\end{array}$ & $\begin{array}{c}\text { Gaya } \\
\text { Jakarta }\end{array}$ & $\begin{array}{c}\text { Gaya } \\
\text { Solo }\end{array}$ & $\begin{array}{c}\text { Gaya } \\
\text { Surabaya }\end{array}$ \\
\hline Ukulele & $\begin{array}{l}\text { Dua buah } \\
\text { stem A } \\
\text { dan E, } \\
\text { digaruk }\end{array}$ & $\begin{array}{l}\text { Stem } \mathrm{A}, \\
\text { digaruk }\end{array}$ & $\begin{array}{l}\text { Stem A, } \\
\text { dipetik } \\
\text { 'Kentlulul } \\
\text { ul' }\end{array}$ & $\begin{array}{l}\text { Stem A, } \\
\text { digaruk dan } \\
\text { dipetik } \\
\text { 'Kentlululul' }\end{array}$ \\
\hline Banjo & --- & $\begin{array}{l}\text { Dipetik } \\
\text { satu senar } \\
\text { saja }\end{array}$ & $\begin{array}{l}\text { Digaruk } \\
\text { akor } \\
\text { lengkap }\end{array}$ & $\begin{array}{l}\text { Digaruk akor } \\
\text { lengkap }\end{array}$ \\
\hline Gitar & $\begin{array}{l}\text { Gitar } \\
\text { lebih dari } \\
\text { satu, not } \\
\text { sinkup } \\
\text { dan } \\
\text { treiul, } \\
\text { terkadang } \\
\text { ditambah } \\
\text { mandolin }\end{array}$ & $\begin{array}{l}\text { Irama } \\
\text { grebekan, } \\
\text { tenang } \\
\text { lalu tiba- } \\
\text { tiba cepat }\end{array}$ & $\begin{array}{l}\text { Cenderun } \\
\mathrm{g} \text { tenang } \\
\text { saja }\end{array}$ & $\begin{array}{l}\text { Irama } \\
\text { demungan, } \\
\text { konstan } \\
\text { mengiringi } \\
\text { vokal }\end{array}$ \\
\hline
\end{tabular}

\begin{tabular}{|c|c|c|c|c|}
\hline Celo & --- & $\begin{array}{l}\text { Celo } \\
\text { lincah, } \\
\text { tidak } \\
\text { melan } \\
\text { kolis }\end{array}$ & $\begin{array}{l}\text { Banyak } \\
\text { variasi, } \\
\text { meniru } \\
\text { gaya } \\
\text { kendang, } \\
\text { melan } \\
\text { kolis }\end{array}$ & $\begin{array}{l}\text { Improvisa } \\
\text { toris, tidak } \\
\text { terlalu } \\
\text { melankolis }\end{array}$ \\
\hline $\begin{array}{l}\text { Kontra } \\
\text { bas }\end{array}$ & --- & $\begin{array}{l}\text { Dipetik } \\
\text { Bas dan } \\
\text { kontranya }\end{array}$ & $\begin{array}{l}\text { Tidak } \\
\text { hanya bas } \\
\text { dan } \\
\text { kontra } \\
\text { yang } \\
\text { dibunyi } \\
\text { kan }\end{array}$ & $\begin{array}{l}\text { Bagian } \\
\text { tertentu } \\
\text { dipetik bas } \\
\text { dan kontranya } \\
\text { saja, bagian } \\
\text { lain } \\
\text { ditambahkan } \\
\text { pemanis } \\
\text { sebagai variasi }\end{array}$ \\
\hline Flute & --- & $\begin{array}{l}\text { Saling isi } \\
\text { dengan } \\
\text { biola }\end{array}$ & $\begin{array}{l}\text { Saling isi } \\
\text { dengan } \\
\text { biola, } \\
\text { tidak } \\
\text { arogan/ } \\
\text { samar } \\
\text { menjadi } \\
\text { backgrou } \\
\text { nd vokal }\end{array}$ & $\begin{array}{l}\text { Saling isi } \\
\text { dengan biola, } \\
\text { tidak arogan/ } \\
\text { sama menjadi } \\
\text { background } \\
\text { vokal }\end{array}$ \\
\hline Biola & --- & $\begin{array}{l}\text { Saling isi } \\
\text { dengan } \\
\text { flute }\end{array}$ & $\begin{array}{l}\text { Saling isi } \\
\text { denga } \\
\text { flute }\end{array}$ & $\begin{array}{l}\text { Saling isi } \\
\text { dengan flute, } \\
\text { berbunyi juga } \\
\text { saat vokal } \\
\text { mengambil } \\
\text { napas }\end{array}$ \\
\hline Lirik & $\begin{array}{l}\text { Alam, } \\
\text { kepahla } \\
\text { wanan }\end{array}$ & $\begin{array}{l}\text { Alam, } \\
\text { kepahlaw } \\
\text { anan }\end{array}$ & $\begin{array}{l}\text { Alam, } \\
\text { kepahla } \\
\text { wanan }\end{array}$ & $\begin{array}{l}\text { Alam, } \\
\text { kepahlawa } \\
\text { nan, kritik } \\
\text { sosial }\end{array}$ \\
\hline $\begin{array}{l}\text { Harmo } \\
\text { nisasi }\end{array}$ & $\begin{array}{l}\text { Tonika, } \\
\text { sub } \\
\text { dominan, } \\
\text { dominan }\end{array}$ & $\begin{array}{l}\text { Tonika, } \\
\text { sub } \\
\text { dominan, } \\
\text { dominan }\end{array}$ & $\begin{array}{l}\text { Tonika, } \\
\text { sub } \\
\text { dominan, } \\
\text { dominan }\end{array}$ & $\begin{array}{l}\text { Tonika, sub } \\
\text { dominan, } \\
\text { dominan, } \\
\text { ditambah } \\
\text { super tonika, } \\
\text { sub median, } \\
\text { tonika7 dan } \\
\text { tonika6 }\end{array}$ \\
\hline
\end{tabular}

Berdasarkan tabel 2 dapat disimpulkan bahwa bentuk dan gaya penyajian keroncong gaya Surabaya memiliki persamaan perbedaan dengan gaya Lama, gaya Jakarta, maupun gaya Solo ditinjau dari bentuk, harmoni, ritme, spesifikasi instrumen musik, serta pembawaannya. Spesifikasi instrumen keroncong gaya Surabaya telah dimodifikasi sehingga memiliki beberapa perbedaan dari instrumen regularnya. Perbedaan itu terletak pada bahan dawai maupun pada aturan stemnya. 


\section{Kepustakaan}

Any Andjar. 19797. Musik Keroncong Menjawab Tantangan Jamannya, Proseding Seni Musik oleh Direktorat Kesenian di Cisarua Bogor, 3-12 September) hal 2.

Budiman, BJ. 1979. Mengenal Keroncong Dari Dekat, Jakarta: Tanpa Penerbit. Hal 42.

Desrilland. 2001. "Keroncong Musik Khas Indonesia: sebuah Kajian Musikologis", (Tesis untuk meraih gelar Magister Humaniora, Program Pengkajian Seni Pertunjukan Universitas Gadjah Mada. Jogjakarta: Program Pasca Sarjana Universitas Gadjah Mada). Hal. 1, 42-47
Ernst Heins. 1975. Kroncong and TanjidorTwo cases of urban folk music in Jakarta. Asian Musik VII-I, Journal of the society for Asian Music. Hal. 21

Harmunah, 1987. Musik Keroncong (Sejarah, Gaya dan Perkembangan). Jogjakarta: Pusat Musik Liturgi. Hal 9-10, 17.

Prier, Karl-Edmund, 1996, Ilmu Bentuk Musik, Yogyakarta: Pusat Musik Liturgi. Hal 2.

Poerwadarminta, W.J.S.. 2003. Kamus Umum Bahasa Indonesia. Jakarta: Balai Pustaka. Hal. 354.

Zandra, R. A. (2014). Sejarah Musik Keroncong di Surabaya. Imaji. https://doi.org/10.21831/imaji.v12i1.3 634 